University of California, Hastings College of the Law UC Hastings Scholarship Repository

Faculty Scholarship

1992

\title{
Sentencing Guidelines and Mandatory Minimums: The Need for Separate Evaluation
}

William W. Schwarzer

UC Hastings College of the Law, schwarzw@uchastings.edu

Follow this and additional works at: https://repository.uchastings.edu/faculty_scholarship

\section{Recommended Citation}

William W. Schwarzer, Sentencing Guidelines and Mandatory Minimums: The Need for Separate Evaluation, 4 Fed. Sent. R. 352 (1992). Available at: https://repository.uchastings.edu/faculty_scholarship/1339

This Article is brought to you for free and open access by UC Hastings Scholarship Repository. It has been accepted for inclusion in Faculty Scholarship by an authorized administrator of UC Hastings Scholarship Repository. For more information, please contact wangangela@uchastings.edu. 


\section{SENTENCING GUIDELINES AND MANDATORY MINIMUMS: THE NEED FOR SEPARATE EVALUATION}

\author{
William W Schwarzer*
}

Evaluation of the operation of the sentencing guidelines is currently the focus of much study and discussion. The Sentencing Commission recently issued its four-year report, the General Accounting Office is engaged in a study, and academics and practitioners are devoting attention to the subject. Because of the profound impact of sentencing guidelines on the administration of criminal justice, careful study and clear analysis are essential.

Two factors muddy such analysis. First, mandatory minimum sentencing statutes operate concurrently with the guidelines and, indeed, formed the basis for the Commission's drug guidelines. It is therefore not possible to disentangle the effects of mandatory minimums from those of the sentencing guidelines. Second, the data bases available to researchers in the sentencing area were not designed for this evaluation and have their limitations. Quantitative assessments must therefore be viewed with caution, conclusions tempered with some skepticism, and final judgments reserved. Nevertheless, significant data are emerging from the research that deserve attention and warrant consideration in policy making.

Recent research by the Federal Judicial Center has focused on the sentencing of drug offenders across a seven year period during which both mandatory minimums and sentencing guidelines began having their effect. The primary interest was in the impact of the mandatory minimum sentencing laws. ${ }^{1}$ Regrettably, there were no data bases that distinguished sentences imposed under mandatory minimum laws. It was therefore not possible to identify, collect and analyze cases disposed of under those laws. ${ }^{2}$ But it was possible, using information coded from presentence reports, to study drug convictions and determine which cases involved drug amounts that warrant a sentence under the mandatory minimum laws (whatever sentence was actually imposed).

\section{THE CONTINUED EXERCISE OF DISCRETION}

A study conducted primarily by Dr. Barbara Meierhoefer of the Center demonstrates how certain sentencing factors have influenced the length of sentences imposed on drug offenders over time. ${ }^{3}$ The influential factors for both offenders with mandatory minimum behaviors and other drug

* Director, Federal Judicial Center. The opinions expressed in this article are not necessarily those of the Center or its Board. offenders are: drug type and amount, prior record, role in the offense, gender and race.

Putting aside drug type, drug quantity and prior offenses, which are the operative sentencing factors under the mandatory minimum statutes, it is curious that the other identified factors should influence the sentencing of offenders with mandatory minimum behavior when the statute by its terms bars their consideration, at least for sentencing below the minimum. ${ }^{4}$

Were mandatory minimum laws applied automatically to the statutory offense behaviors, letting the chips fall where they may, one would expect that, after 1986 (when the mandatory minimum drug laws were enacted), the differences in the sentences for mandatory minimum behaviors would differ little based on role in the offense, gender, and race. Instead, since 1986, the sentences for the more culpable drug offenders remain more than double those for similarly situated less culpable drug offenders; males continue to receive sentences about 40 percent higher than those of females; and the difference between average sentences imposed on black and white offenders has increased (from 28 percent in 1984 to 49 percent in 1990). A racially disparate impact of mandatory minimum sentences is further demonstrated by the fact that, among defendants whose behavior warranted imposition of mandatory minimum sentences, non-white defendants received the mandatory prison term 20 percent more often than white defendants. Moreover, of all cases in which the offense behavior warranted imposition of a mandatory minimum sentence, a sentence at or above that level was imposed only 60 percent of the time.

The irony that emerges is that discretion intrudes even into the most rigid sentencing scheme. If that is true, one might well ask: why give it all to advocate prosecutors and none to neutral judges? The purpose of Congress-to send a message to drug dealers that if you sell, e.g., 5 grams of crack, you'll go to prison for five years-is not being accomplished. Congressional and administration supporters of mandatory minimum sentencing should have doubts about the validity of their underlying assumptions in light of this evidence of discretionary application. ${ }^{5}$ It is not that the sentencing scheme is not tough and rigid enough, but rather that the tougher and more rigid one seeks to make it, the more determined the effort (and the greater the need) to evade it.

\section{THE CRACK-POWDER COCAINE INEQUITY} The most disturbing data to come out of the study are those suggesting racial disparity in the application of mandatory minimum laws. One can only speculate about the explanation for this phenomenon. Presumably, racial animus is not a factor in the exercise of prosecutorial discretion. But it is quite likely that mandatory minimums have a disproportionate impact on defendants charged with the sale and distribution of crack. ${ }^{6}$ The penalties for crack are one hundred times as heavy as those for cocaine, e.g., 5 grams of so-called cocaine base (crack) is treated 
the same as 500 grams of cocaine; 50 grams of crack is treated the same as 5 kilos of cocaine; and, incidentally, crack is treated 20 times more severely than heroin. As a result, even small street-level crack dealers become subject to severe mandatory minimum sentences and are caught up in the net of federal prosecutions. This, in turn, means not only that crack defendants are disproportionately black, but also that most of them will be small timers who have little of value to offer the prosecutor to bargain for a reduced charge or a downward departure for substantial assistance (authorized under the statute only on motion of the government). By way of comparison, dealers in large quantities of cocaine are more likely to have information about their chain of distribution that the government would consider worth bargaining for.

This situation results from the 1986 Anti-Drug Abuse Act which prescribed these increased penalties for crack. Its legislative history reveals great concern in Congress over a national crack epidemic, stimulated by the then recent deaths of Len Bias, the basketball player, and Don Rogers, a football player. Crack, which can be smoked, was regarded as much more addictive than cocaine. And because crack was effective in smaller quantities, it was thought to be more readily available to the youth market. For these reasons the existing drug laws were considered inadequate to deal with the perceived dangers.

The extreme disparity between crack and cocaine penalties, and its accompanying racially disparate impact, have raised questions concerning a potential violation of the equal protection clause. Federal courts of appeals have so far rejected constitutional attacks on the treatment for crack offenders. But in Minnesota v. Russell, 477 NW2d 886 (1991), the Minnesota Supreme Court declared that state's statute, under which possession of 3 grams of crack is punished the same as possession of 10 grams of cocaine, to be unconstitutional as applied. The court found that the evidence did not support the underlying premise of the statute that possession of the required amount signified that the person was a dealer. It also found insufficient evidence to support a distinction based on the relative danger and addictive quality of crack and cocaine. Most significantly, the court found that, of the persons charged with crack possession, 97 percent were black; of the persons charged with cocaine possession, 80 percent were white.

\section{INCENTIVES TO PLEAD GUILTY}

Putting aside the problem of disparate racial impact, the Center's study shows more generally the significant effect of the prosecutor's power over charging decisions and downward departures for substantial cooperation. Notwithstanding the total absence of judicial discretion to sentence below the minimums, it appears that some defendants at least are able to negotiate out of mandatory minimum sentences. Although specific data linking sentences to the statutes are not available, it is not disputed that decisions about charging, bargaining, and motions for downward departures result in below-minimum sentences for behavior within the statutes.

A failure to gain a favorable charge or departure decision by the prosecutor, whether as a part of a plea bargain or otherwise, has devastating consequences for a defendant subject to mandatory minimums. To illustrate:

- simple possession of one gram of crack carries a five year mandatory minimum if it is a third offense;

- distribution of 10 grams of crack carries a 5 year minimum, or ten years if it is a second drug felony conviction;

- distribution of 50 grams of crack carries a 20 year minimum if the defendant had a prior drug felony conviction-federal, state or foreign-and mandatory life without parole after two prior felony convictions.

Faced with such penalties, and no possibility that judicial sentencing discretion can intervene, defendants often conclude that there is little to be lost by going to trial, unless the egregiousness of the offense disclosed by the evidence might lead a judge to impose a sentence above the minimum after trial. It is safe to say, therefore, that the risk of mandatory minimum sentences provides a powerful impetus to go to trial.

The incentives under the mandatory minimums are profoundly different from those under the sentencing guidelines. While substantially restricting judicial discretion, the guidelines nevertheless offer some incentives to plead guilty: both the adjustment for acceptance of responsibility and that for obstruction of justice operate to serve that end. At the middle levels of the guideline table, the twolevel adjustment for acceptance of responsibility can produce a spread between the high and low of the guideline range of well over a year, and in the higher criminal history categories of three years or more. Moreover, the guidelines afford opportunities for negotiation to lessen the sentence in other areas, such as relevant conduct and role in the offense.

\section{IMPLICATIONS FOR EVALUATION}

These distinctions between sentencing under mandatory minimums and the guidelines must be kept in mind when assessing sentencing data. In particular, any evaluation of the impact of the sentencing guidelines on guilty plea rates and trial rates will require careful analysis. There is evidence tending to show that plea rates in drug and weapons cases are declining whereas those for other types of offenses are increasing. ${ }^{7}$ The decline in plea rates in drugs and weapons cases, many of which are subject to mandatory minimums, may reflect the lack of incentives to plead under the mandatory minimum statutes rather than the impact of the sentencing guidelines per se. While it is generally undisputed that sentencing guidelines have made sentencing more time-consuming and burdensome for district judges-not to mention appellate judges who must 
hear appeals from sentencing decisions-it is far from clear that the guidelines have affected the rate of pleas and trials. Assessing the impact of the guidelines on plea and trial rates in drug and weapons cases subject to mandatory minimum sentences which the sentencing guidelines incorporate is therefore highly problematical.

A fair evaluation of the operation of the guidelines will require the development and segregation of mandatory minimum data. And it would also be aided considerably if the Sentencing Commission would develop guidelines for drug cases independent of the mandatory minimums. Though mandatory minimums would trump the guidelines in any case in which they apply, separating guideline convictions from those driven by mandatory minimums would make it possible to evaluate the operation and impact of each system fairly and accurately.

\section{FOOTNOTES}

${ }^{1}$ Although such a time series analysis does not allow unequivocal attribution of changes to particular circumstances, noticeable changes in sentencing that occurred in 1987 , following enactment of mandatory minimum statutes, but before guidelines, are taken to suggest an effect of these laws.

${ }^{2}$ This deficiency should be remedied in future studies. The Sentencing Commission has been collecting data since early 1989 on whether the charge of conviction carried a mandatory minimum term. The Commission's Monitoring Unit, however, considers these data of questionable reliability based on samples they have drawn to study the effect of minimums.

${ }^{3}$ B. Meierhoefer, The General Effect of Mandatory Minimum Prison Terms: A Longitudinal Study of Federal Sentences Imposed (Federal Judicial Center, in press); B. Meierhoefer, "The Role of Offense and Offender Characteristics in Federal Sentencing," paper presented at the Federal Sentencing Symposium, University of Southern California Law Center (February, 1992).

+The statutes do, of course, allow courts to impose sentences above the minimum, in conformity with the sentencing guidelines, but the minimum is generally so high that the exercise of upward discretion is not a significant factor in the analysis of the operation of mandatory minimum statutes.

${ }^{5}$ In addition, the efficacy of using severe sentences as potential deterrents for groups of offenders who do not believe they will be caught has always been questionable.

${ }^{6}$ The supposition cannot be tested directly because the available data bases do not differentiate between crack and powder cocaine. The Sentencing Commission is now in the process of implementing a data module that will include this distinction.

${ }^{7}$ T. Dunworth and C. Weisselberg, "Felony Cases and the Federal Courts: The Guidelines Experience," paper presented at the Federal Sentencing Symposium, University of Southern California Law Center (February, 1992). 